\title{
A Kaleckian Analysis of Monetary Policy
}

\author{
Malcolm Sawyer ${ }^{*}$
}

This paper has the simple objective of exploring the implications of a Kaleckian (heterodox) macroeconomic analysis for the effectiveness of monetary policy, specifically one based on the use of interest rates to target the rate of inflation. The paper begins by setting out the essential features of a Kaleckian macroeconomic analysis in terms of the role of aggregate demand and money, and considering the nature of the supply-side of the economy. Some features of that analysis are drawn out and implications are drawn for the nature and effectiveness of monetary policy.

JEL classifications: EI2, ESO

Keywords: monetary policy, Kalecki, macroeconomic analysis

\section{Introduction}

This paper has a simple objective, namely starting from some basic propositions of a Kaleckian (heterodox) macroeconomic analysis to explore the implications for the effectiveness of monetary policy, specifically a monetary policy based on the use of interest rates to target the rate of inflation. We proceed by briefly setting out the essential features of a Kaleckian macroeconomic analysis particularly with regard to the production supply side. Some features of that analysis are then developed, and the paper is completed by drawing out implications of that analysis for the effectiveness of monetary policy.

* University of Leeds.

Correspondence address:

Prof. Malcolm Sawyer, Economics Division, Leeds University Business School, The University of Leeds, Leeds LS2 9JT, United Kingdom, e-mail: mcs@lubs.leeds.ac.uk

Received 12 Feb 2006, accepted 22 May 2006

(C) InTERVENTION 3 (2), 2006, 331-349 


\section{Aggregate Demand and Money}

It is common place to observe that the level of economic activity is demand-determined in the short run, and that fluctuations in the level of economic activity arise from fluctuations in demand. The Kaleckian analysis views the significance of the role of aggregate demand as more extensive than that. Specifically, the absence of market-based forces leading the level of demand into line with available supply is one basic tenet of a Kaleckian analysis and hence inadequate aggregate demand can be a long-term phenomenon. Further, the evolution of the supply potential of the economy in terms of the available work force, the size of the capital and the growth of factor productivity are all strongly influenced by the time path of the level of demand. This is most evident for the growth of the capital stock, where investment expenditure is strongly influenced by the level of economic activity, but it would also be relevant for the evolution of the effective labour force.

The level of aggregate demand depends, of course, on the sum of intended consumer demand, investment demand and government expenditure plus the net trade balance. Since the propensity to consume depends on the income source (wages versus profits), and investment is influenced by profitability for a variety of reasons, the distribution of income between wages and profits plays a significant role in the determination of aggregate demand. The level of economic activity itself (as reflected in capacity utilisation, level of unemployment) impacts on the level of aggregate demand.

Investment decisions involve commitments and rewards which extend far into the future, and when the future is viewed as inherently uncertain investment decisions cannot be approached through optimisation under full information about a pre-determined future. Investment decisions (along with many others) are not then approached through seeking to set up some optimisation problem from which first order conditions are derived to be used for an investment equation. Recent and current experience along with views about the future will have a strong influence on investment. Hence investment is path dependent, and specifically is influenced by the path taken by demand and economic activity, and reflected in variables such as profitability and capacity utilisation. There is no sense in which the future time path of the capital stock can be seen as pre-determined by relative prices (as in the neo-classical approach). When investment and hence the evolution of the capital stock are path dependent, then macroeconomic policies have an influence on investment, and thereby on the evolution of the supply side of the economy as investment adds to the capital stock.

The variables which impact on investment are particularly significant for the effects or otherwise of monetary policy. In the Kaleckian tradition we postulate that profits (current and anticipated) and capacity utilisation (level and change) are significant (see, for example, Lavoie I992: chapter 6, Sawyer I982: 99 ff. and I55 f., Mott 2003). The inclusion of profits comes from a range of considerations. Current profits provide a potential pool of funds for the internal financing of investment. They may also be used as a signal of future profitability. Capacity utilisation clearly relates to the idea that firms are undertaking investment in order to add to the capital stock to be able to produce higher levels of 
output in the future. Underutilised capacity would dampen the need to undertake investment for that purpose.

Investment expenditure has to be financed, and hence the conditions under which finance is made available are significant. Kalecki provided the essence of the argument here:

"[T]he possibility of stimulating the business upswing is based on the assumption that the banking system, especially the central bank, will be able to expand credits without such a considerable increase in the rate of interest. If the banking system reacted so inflexibly to every increase in the demand for credit, then no boom would be possible on account of a new invention, nor any automatic upswing in the business cycle. [...] Investments would cease to be the channel through which additional purchasing power, unquestionably the primus movens of the business upswing, flows into the economy« (Kalecki 1990: 489).

The cost of finance may also have some influence on investment decisions, though the relationship between the perceived rate of profit and the long-term rate of interest would be particularly relevant.

This general approach is consistent with much evidence on investment. Chirinko (1993) summarises a wide range of evidence on investment spending.

"Although these and other empirical results with version of the Neoclassical Model differ widely, they suggest to this author that output (or sales) is clearly the dominant determinant of investment spending with user cost having a modest effect" (Chirinko 1993: 188I).

and: "Regarding empirical determinants, it appears that investment is most sensitive to quantity variables (output or sales) with price variables having only modest effects" (Chirinko 1993: 1883). Baddeley (2003: 214) in a comprehensive study of investment also confirms the results of "previous analyses that capacity utilization and output have the strongest effects on aggregate investment activity."

In an open economy, the contribution of the foreign sector to net aggregate demand has to be considered by reference to imports and exports and the influences of world and domestic income and the exchange rate. In the present context, the significant element is the influence of the exchange rate on the net trade position, and also the influence of interest rates on the exchange rate. As the Bank of England states,

"changes in interest rates can also affect the exchange rate. An unexpected rise in the rate of interest in the UK relative to overseas would give investors a higher return on UK assets relative to their foreign-currency equivalents, tending to make sterling assets more attractive. That should raise the value of sterling, reduce the price of imports, and reduce demand for UK goods and services abroad. However, the impact of interest rates on the exchange rate is, unfortunately, seldom that predictable« (Bank of England 2006: I). 
Money is credit money endogenously created within the private sector with loans created by banks generating bank deposits. The expansion of the stock of money is driven by the demand for loans, which leads to the expansion of bank deposits in so far as the demand for loans is met by the banking sector. However, the stock of money has to be held by people, and the stock of money is largely determined by the sdemand for money<, as money can also be destroyed by the repayment of loans.

The Central Bank sets the key discount rate which governs the terms on which the Central Bank provides sbase money` (Mo) to the banking system. The setting of this discount rate has always been a highly significant component of monetary policy, and in many cases currently monetary policy has become synonymous with the setting of this interest rate.

The monetary system has three key elements. First, money is largely or wholly bank money and hence money is created by the private banking system in the process of supplying loans. The supply of loans is crucial to the expansion of demand and of expenditure. Second, the amount of money remaining in circulation is essentially determined by the willingness of the public to hold money (the >demand for money`), and hence the stock of money is essentially demand-determined. This rules out the notion of rexcess money, and the effects which stoo much money represented by the setting of a key discount rate by the Central Bank.

An increase in loans outstanding is then accompanied by some increase in reserves, which are matched by an increase in bank deposits. The loans which are granted create bank deposits, and thereby immediately increase the amount of money in existence. These bank deposits circulate as individuals and firms spend them and others receive them. However, those households and firms with loans outstanding may decide to use the deposits received to pay off loans, thereby extinguishing both loans and deposits. The amount of deposits which continue in existence then depends on the willingness of people to hold bank deposits. Allowing for some time of adjustment, the amount of money in existence is essentially determined by the demand for money.

The stock of money is something of a residual in that it is determined by the willingness of the public to hold money, which in turn depends on factors such as the level of nominal income. The stock of money itself does not have any causal effects (and specifically does not feed back to influence the level of income or the rate of inflation). There then appears to be little reason to discuss the ‘demand for money`.

The expansion of expenditure can only take place if it can be financed, and this usually requires the take up of loans. As loans are granted, bank deposits also expand, and these circulate. However, much of the expansion of bank deposits will in effect be used to pay off loans. When someone with an outstanding loan receives a bank deposit, they have a choice as to whether or not to pay off part of the loan: if they do so, then repayment of the loan extinguishes the bank deposit. As the transactions demand for money grows, the amount of bank deposits remaining in existence also grows. Thus it would be expected that the growth of the money in existence would match the rate of inflation, but the causation runs from inflation to growth of money rather than in the reverse direction. 
The key nominal interest rate is set by the Central Bank. Interest rates on bank deposits and on bank loans are viewed as set by banks as a mark-down and mark-up over the discount rate respectively. The relationship between the interest rates on loans and on deposits with the discount rate can be expected to depend on the degree of market power of the banking system and on their attitudes to risk and liquidity.

\section{Supply Side}

The supply side is approached in terms of two elements, namely prices and output, and wages and employment, and their interaction. In doing so, we are able to indicate the role of the distribution of income as between wages and profits, the influence of the capital stock on the supply side, and to say something on the inflationary process. In the context of examining the effectiveness of monetary policy, it is clearly highly relevant to have a view on the nature of the inflationary process. Further, it is important to examine the nature of any supply-side equilibrium and the interaction between the demand side and supply side. In the approach here, particular attention is given to the linkages from demand to investment through to the supply potential of the economy.

In the short term, the productive capacity of the economy (in terms of capital equipment) is taken as given. In the longer term, investment in capital equipment adds to productive capacity. The decisions made by firms on prices (relative to wages) and on output depend on the level of aggregate demand and the amount of productive capacity.

\section{I Prices and Output}

The individual enterprise faces a demand for its products which depends on the general level of aggregate demand in the economy and on the prices charged by its competitors. Its costs depend on the wages which it pays and its material costs, and the enterprise may well set the wage in its own strategic interests and in particular with regard to the effect which the wage will have on worker morale, work effort and productivity (i.e. efficiency wages). But the costs of the enterprise and its ability to provide employment will depend on its level of productive capacity.

For a particular set of aggregate demand and cost conditions facing the enterprise, a particular price (hence real product wage equal to wage divided by price) and a particular level of output (and hence level of employment to produce that output) will be chosen by the enterprise. As the level of aggregate demand varies, so do the levels of production and employment offered vary. As output varies, the costs of production may change: at low levels of output, unit costs may well fall as output increases though at high levels of output it could be expected that unit costs begin to rise. In so far as prices follow unit costs, prices would fall as output increased and then rise, and correspondingly the real product wage would rise and then fall (see figure I, p. 336). 
Figure I: Illustration of the p-curve

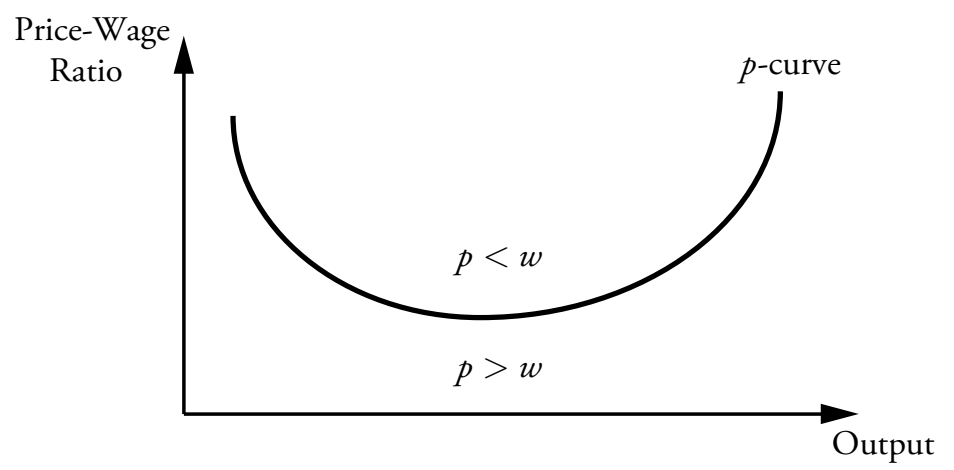

A firm sets its price $(P)$ as a mark-up $(m)$ over average direct costs $(A D C)$ :

$$
P=\frac{A D C}{1+m},
$$

which can be written as $P=\left(\frac{W}{A P L}+\frac{F}{A P M}\right)(1+m)$ and then

$$
\frac{P}{W}=(1+m)\left(\frac{1}{A P L}+\frac{F}{W} A P M\right)
$$

where $W$ is money wage, $F$ is cost of materials, $A P L$ average product of labour, APM average product of materials. This is the relationship between price-wage ratio and output drawn as the $p$-curve in figure $\mathrm{I}$. This equation for the price-wage ratio clearly depends on the mark-up applied by enterprises, and any increase (decrease) in the market power of enterprises leading to a larger (smaller) mark-up would shift the $p$-curve upwards (downwards).

The desired price $P$ can then be seen to be a function of the money wages, the cost of materials and the level of output (which will influence the mark-up and the level of marginal costs). At the aggregate economy level, materials are those which are imported (as domestically produced material can be decomposed into a labour input and a material input).

The move from the enterprise level to the economy level proceeds as follows: for a specified level of aggregate demand, there is a resulting amount of output which the enterprise seeks to produce, and adding those output decisions together gives the total level of output. There is also a price-wage ratio for each enterprise, and the average price-wage ratio is obtained by a suitably weighted average of the individual ratios.

A move along the $p$-curve corresponds to variations in the (perceived) level of aggregate demand. It is not a matter of an enterprise choosing some combination of output and price-wage ratio, but rather that for a particular level of aggregate demand there is one combination which is in the enterprise's interests. The expansion of output requires 
an expansion of aggregate demand, rather than a change in the price-wage ratio (though such a change in that ratio may come about as a consequence of the change in aggregate demand). But as the level of aggregate demand changes, so will the price-wage ratio and the level of output, and those changes will map out the $p$-curve.

From the notion that price depends on wages, material costs and the level of output, the rate of price inflation $(p)$ then depends upon the recent rate of change of money wages $(w)$ and of imported materials $(f)$, the rate of change of output $q$ and a catch-up term which is a proportion of the difference between the desired price and the actual price. There may be a range of lags between costs and prices, but these lags are represented here in the simplest way. This can be expressed as:

$$
p=b w_{-1}+(1-b) f_{-1}+c q+\theta\left(\left(\frac{P}{W}\right)^{*}-\left(\frac{P}{W}\right)_{-1}\right),
$$

which can be readily re-written as

$$
p-w_{-1}=(1-b)\left(f_{-1}-w_{-1}\right)+c q+\theta\left(\left(\frac{P}{W}\right)^{*}-\left(\frac{P}{W}\right)_{-1}\right),
$$

where $c$ may be positive or negative.

The movement of price inflation relative to wage inflation depends on three factors. The first is a measure of imported inflation $\left(f_{-1}-w_{-1}\right)$, the second the change in the level of output, $q$, and the third an adjustment factor related to the difference between desired price (relative to wages) and actual price (relative to wages).

The first term suggests that an upsurge in world inflation (not offset by an appreciation of the domestic currency) would generate a form of cost-push inflation. The rate of change of output can influence price inflation in a positive or negative manner. For example, at relatively low levels of output, average direct costs fall as output expands, and from that perspective the prices fall (relative to money wages) as output expands, i.e. the $c$ coefficient in the equation would be negative. The adjustment factor brings in the role of the level of output in that the output level influences the desired price-wage ratio.

In terms of the $p$-curve, for combinations of price-wage ratio and output below the curve, prices would tend to rise faster than wages, and for combinations above the curve prices tend to rise slower than wages, and this is signified in figure I. These tendencies would be modified by what was happening to foreign inflation and by the effects of recent changes in output.

The output produced and the employment offered in total by the enterprises depends on the amount of capacity which the enterprises have. Thus the position of the $p$-curve in figure I depends on the amount of productive capacity. An increase in the capital stock which represents an increase in the capital intensity of production will raise labour productivity and shift the $p$-curve downwards. Output is a function of the capital stock, employment and material inputs: an increase in the capital stock raises the productivity of labour, reduces average direct costs and thereby shifts the $p$-curve (for a much more extensive discussion see Sawyer 2002). 


\subsection{Wages and Employment}

A relationship between price-wage ratio and output based on wage determination is now derived. The approach used here is based on the idea of efficiency wages. At the enterprise level money wages $(W)$ are viewed as set relative to alternative (expected) income $(A)$ of the workers. The mark-up $\mu$ of the wage over the alternative income (relative to the wage) can be viewed as depending on a variety of factors such as the bargaining strengths of the enterprise and trade unions, and/or on efficiency wage considerations. These alternative determinants lead to very similar formulations, and we work here with a general formulation. The alternative income is a weighted average of wages elsewhere and of the level of unemployment benefits $(B)$ where the weights depend on the level of unemployment. The general form is then:

$$
\begin{gathered}
\frac{W-A}{W}=\mu, \\
A=(1-\lambda U) W^{e}+\lambda U B,
\end{gathered}
$$

where $W^{e}$ is the alternative wage outside of the enterprise and $U$ the level of unemployment and $\lambda$ a factor reflecting the rate of labour turnover and the rate of discount (and hence the cost of job search). The formulation of the alternative income reflects the idea that a worker leaving the enterprise may expect to spend sometime unemployed during which unemployment benefits $B$ would be received and other time in employment paying the alternative wage $W^{e}$.

The equilibrium is characterised by all enterprises paying the same wage, and hence the condition that $W=W^{e}$, and solving the equations yields $W / B=\lambda U /(\lambda U-\mu)$. This provides a negative relationship between the ratio of wages to unemployment benefits and the level of unemployment. In terms of logs of relevant variables, this can be written as $\log W-\log B=h(U)$, which can be expanded and expressed in terms of employment as $(\log W-\log P)-(\log B-\log P)=H(L)$ with the first derivative of $H$ assumed to be positive. For given productive capacity, output and employment are related, and we derive a $w$-curve as $(\log P-\log W)-(\log P-\log B)=J(Y)$. The precise mapping between employment and output will change as productive capacity changes.

In figure 2, the top half of the diagram illustrates the relationship between real wage and employment which is viewed as a positive one. The bottom half translates this into a relationship between price-wage ratio and output, and this price-wage-output relationship is labelled the $w$-curve in figure 2 .

The wage dynamics would be expected to be that enterprises would raise money wages faster than prices when wages are low relative to the alternative income, that is when either wages are low or unemployment is low (and hence employment and output high). In terms of figure 2 , for points above the $w$-curve, wages rise faster than prices, whilst for points below wages rise slower than prices. 
Figure 2: Illustration of the w-curve
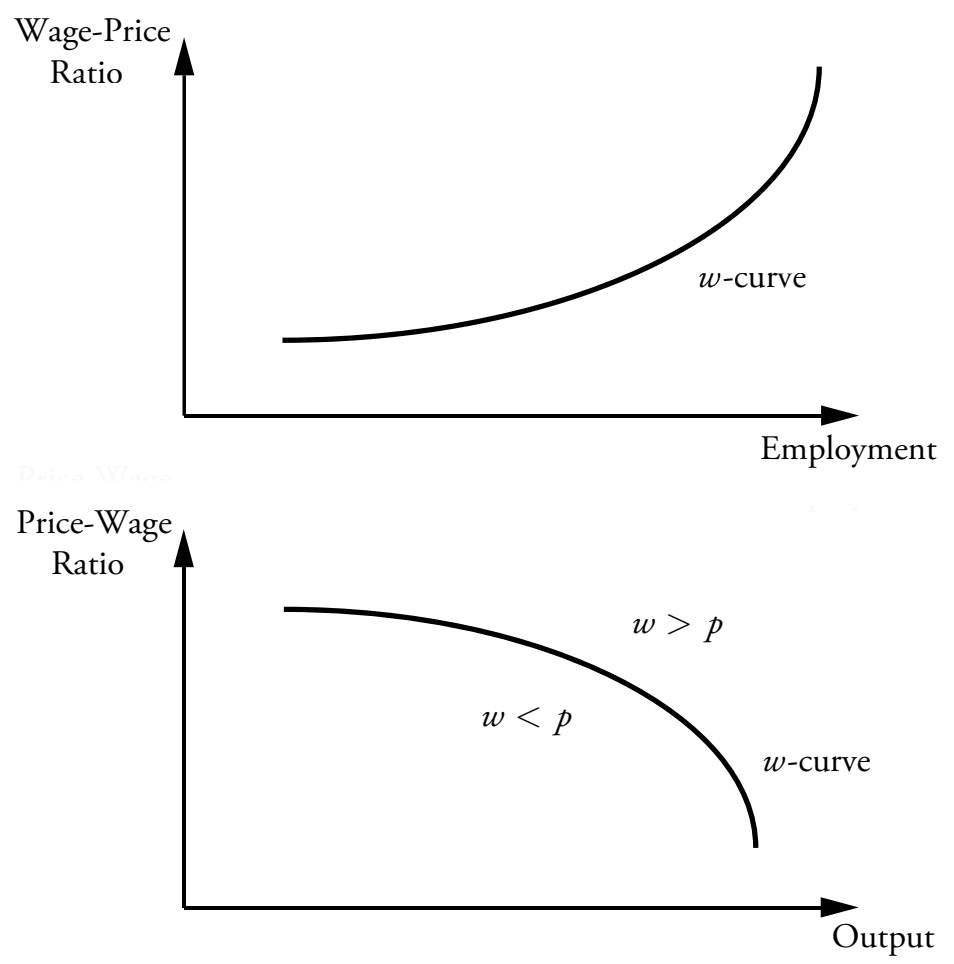

\subsection{Constant Inflation Level of Output (CILO)}

The price and the wage determination processes can now be brought together in figure 3 (p. 340). The intersection of the two curves there appears to provide a supply-side equilibrium, which may be thought of an inflation barrier (Arestis/Sawyer 2005c). This figure is drawn in price-wage-output space rather than wage-price-employment space to seek to avoid suggestions that the labour market plays the key role in the determination of the supply-side equilibrium. It should also be emphasised that there is no presumption here that the supply-side equilibrium is naturak or remains unchanged over time, nor that it acts as strong attractor for the level of economic activity.

Along the $p$-curve, prices would rise in line with wages from price determination considerations, whereas along the $w$-curve wages would rise in line with prices from wage determination considerations. The intersection of the two curves at point $\mathrm{A}$ in figure 3 would provide the constant inflation level of output (CILO) where prices and wages rise at the same rate. This level of output is labelled $Y+$.

Figure 3 appears in two parts. In the upper part the intersection of the two curves occurs where the $p$-curve is downward-sloping which would be where unit costs are declin- 
ing: in the lower part where the $p$-curve is upward-sloping. It can also be readily envisaged that there could be multiple equilibria points. ${ }^{1}$

Figure 3: Determination of the Constant Inflation Level of Output (CILO)

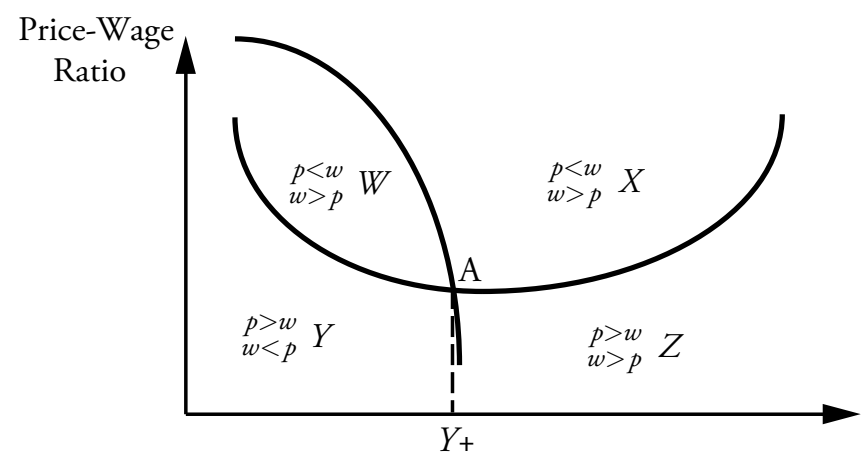

Price-Wage

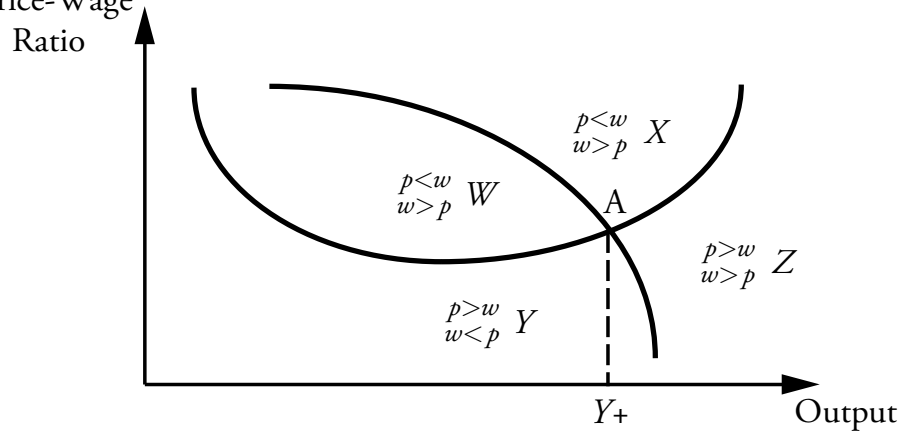

The CILO clearly depends on the position of the $p$-curve and the $w$-curve. In particular this means that increases in productive capacity which shift the $p$-curve outwards lead to a higher level of CILO. There would be a level of employment corresponding to the CILO level of output $Y+$. But there would not be any strong reason why that level of employment would correspond to full employment (or indeed to any particular level of employment). The CILO has some similarities with the non-accelerating rate of inflation (NAIRU). They are levels of output and employment respectively which serve to maintain a constant rate of inflation.

In figure 3 , there are four distinct zones. In each zone, there are two inequalities and the top inequality indicates the relative changes in prices and wages resulting from price determination and the bottom inequality from wage determination. Zone $Z$ is one of rising inflation (associated with relatively high levels of output), whereas zone $W$ is one of

I The $p$-curve at the aggregate level is drawn as a smooth U-shape. But the aggregation from the enterprise level to the economy level could easily lead to a $p$-curve which was far from smooth. This would increase the possibility of multiple equilibria. 
falling inflation (associated with relatively low levels of output). These zones correspond to the positive association between price inflation and level of economic activity. In zone $X(Y)$ the price-wage ratio tends to fall (rise): price inflation would tend to fall (rise) but wage inflation tend to rise (fall).

Changes in the rate of inflation appear to depend on the level of output. For an output other than the CILO, there is a difference between the actual price-wage ratio and at least one of the equilibrium ratios given by the $p$-curve and the $w$-curve. It is the difference between the price-wage ratio and the equilibrium ratio which generates a change in inflation. There are, though, a range of other influences besides the level of output on the pace of inflation. One of these would be the influence of changes in output, whereby on the downward-sloping part of the $p$-curve, increases in output would tend to reduce prices. Hence the effects of an increase in output there would reduce the rate of inflation (as can be seen from the inflation equation given above). For the upward sloping portion of the $p$-curve, an increase in output would tend to increase the rate of inflation.

Equation (4) also indicates another influence on domestic inflation, namely imported inflation. It comes as no surprise that domestic prices will tend to rise faster when imported material costs are rising. This introduces an element into the inflationary process which is not directly affected by the level of demand.

The level of the CILO would be influenced by a range of factors which we briefly list here. The $p$-curve would shift upwards leading to a lower CILO with an increase in the degree of market power (raising the mark-up of price over cost) and with an increase in foreign prices. The $w$-curve would shift inwards (to the south west) also leading to a lower CILO with an increase in the mark-up $\mu .{ }^{2}$ An increase in the number of enterprises in an economy would cause some shift in the $p$-curve towards the right, leading to an increase in the CILO. An increase in capital intensity of production which raises labour productivity would be associated with a downward shift in the $p$-curve.

The CILO has been drawn as though it is a precise point. However, the $p$-curve may well be horizontal over a considerable range which would correspond to constant unit costs with a constant mark-up. The $w$-curve may also be relatively flat. In those circumstances, there may be a CILO range; or at least, output above $Y+$ would involve only rather small increases in inflation. In effect, zone $Z$ in figure 3 could be relatively small, and the pace with which inflation accelerates in that zone relatively low.

The CILO in figure 3 could be seen as akin to a non-accelerating inflation rate of unemployment (NAIRU). But the CILO differs from the NAIRU in (at least) two major respects. First, it is presented in a manner which seeks to emphasise that the interaction of prices and wages and the determination of the level of real wages do not take place in any kind of forum which may be described as sthe labour marketı, and hence the supply-side equilibrium is not set by the features of the labour market. Instead the emphasis is placed on the role of productive capacity. Second, there is no presumption that the CILO acts as

2 In the case of the target real wage approach, an increase in the target real wage would lead the curve to shift inwards. 
a strong (or even weak) attractor for the actual level of economic activity. Simply, there are no market forces which lead the level of aggregate demand to adjust to the CILO.

\section{Inflation}

The analysis of inflation derived from the discussion in the previous section is multi-faceted: inflation and the rise in inflation can have numerous causes with the mix of causes varying over time and across countries. This may be seen as unhelpful - how can policies be designed to combat inflation if the causes vary over time? -, but that may well, we would argue, reflect the reality of the situation.

The ways in which demand influences inflation are not straightforward. It can first be seen by reference to figure 3 that how a specific level of demand (as reflected in the level of output) influences price and wage changes depends on the prevailing price-wage ratio, and that there is not a unique relationship between level of output and price (or wage) changes. Further, as indicated in equation (4), the change of output (and hence of demand) may also have an impact, and the sign of that impact may be positive or negative. This reflects the ambiguity of the effects of higher output on unit costs: when firms are operating with excess capacity, higher output may well be associated with lower unit costs (see also Arestis / Sawyer 2005a). The interaction of the $p$-curve and the $w$-curve in the previous section also serves to illustrate the role of income distribution and the struggle over income shares. An attempt by one group to increase their share in income (e.g. firms seeking higher profits, which would push up the $p$-curve) could spark some increase in inflation, and as other groups seek to restore their income shares inflation persists and may rise further. Cost-push pressures can clearly arise and can emanate from the foreign sector through changes in import prices and in the exchange rate.

The Kaleckian analysis (as in most post-Keynesian analysis, and also with the mainstream new consensus in macroeconomics analysis though that is generally unacknowledged) points to the absence of a causal role for the money supply (and its expansion) in the inflationary process. When money is created (and destroyed) in the loan creation process, it cannot play the helicopter money، role portrayed in the exogenous monetarist story. It is rather that money comes into existence as loans are granted, and the creation of money is a response to the demand for loans (interacting with the willingness of banks to provide loans), and the demand for loans is generally related to a desire to spend. The stock of money must be held by someone whether voluntarily or involuntarily. To the extent that money is held voluntarily in order to satisfy the ^demand for money<, it can be said that the amount of money is demand (for money) determined.

When money is treated as exogenous and under the control of the Central Bank, then it may be plausible to say that inflation is caused by increases in the money supply, and that monetary policy (in the form of control of money supply) is used to target inflation. But we live in a world of endogenous credit money, which is created by the banking system in response to the demand for loans, and loans are required to finance a higher level of 
nominal expenditure. The demand for money rises as the price level rises, and the amount of money remaining in existence is essentially demand-determined. But there is no causal significance in the evolution of the stock of money in line with the price level.

In the context of inflation, the effects of interest rates can be viewed in terms of two channels. The first is the conventional one, namely that interest rates influence demand which influences inflation, though we have cast doubts on the sign and reliability of the link from demand to inflation.

The second one is that interest rates are a cost, and directly and indirectly influence prices. Interest rates can be seen as a direct cost (through the cost of loans) which affects, for example, the costs of holding inventories. For households, mortgage interest payments represent a cost, and whether that cost is reflected in the consumer price index depends on how that index is measured. Interest rates may have an indirect effect on prices through leading firms to seek to raise their profit margins. The Kaleckian approach would highlight this second channel as of some significance, and any way working in the opposite direction to the demand channel.

\section{Perspectives on Monetary Policy}

Monetary policy as it is currently conducted in most industrialised countries has three major features on which we focus here. First, monetary policy in the form of variations in a key policy rate of interest is used to target the rate of inflation. This may take the form of formal inflation targeting (as in the UK) or in a looser sense in which inflation is viewed as the major objective of monetary policy but without a formal target (e.g. USA). The rationale for this can be simply indicated. It is postulated that there is a robust linkage running from interest rates to the level of economic activity to the rate of inflation. This is clearly illustrated in a diagram such as given in figure 4 (p. 344) and in the new consensus in macroeconomics (NCM) models (see, for example, Meyer 200I, and the discussion in Arestis 2007).

Second, the sole objective of monetary policy is the control of inflation. This can be justified on the basis that monetary policy (and more general demand management policies) have no lasting effects on other economic variables such as (un)employment, economic growth and the exchange rate. The expectations-augmented Phillips curve has the attribute that there is a level of economic activity (such as the snatural rate of unemployment) consistent with a constant rate of inflation. Hence, if inflation is to be constant (and specifically if the target rate of inflation is to be achieved), then the level of economic activity has to be at this ssupply-sider equilibrium. It is further assumed that this ssupply-sider equilibrium is unaffected by the time path of the level of economic activity (and of demand). Thus path dependence (of the supply-side equilibrium) is ruled out by assumption. ${ }^{3}$

3 An alternative view would be that demand fluctuates around the supply-side equilibrium, sometimes above, sometimes below, and any effects of demand on the supply-side equilibrium balance out at zero. 
Figure 4: Transmission of Monetary Policy

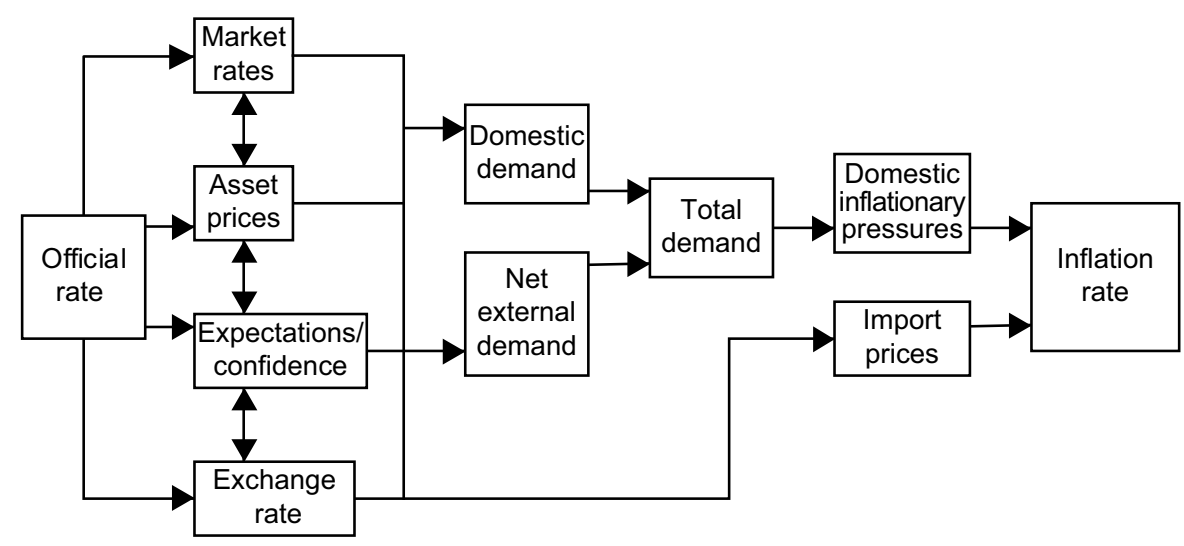

Source: Bank of England (1999)

Third, monetary policy is conducted in an institutional setting in which it is separated from fiscal policy, often through monetary policy being operated by an independent Central Bank. Monetary policy rather than fiscal policy is given the predominant role in guiding the economy. It is further assumed that monetary policy (in the form of the policy interest rate) can achieve the desired level of demand (in the medium term that is one compatible with the supply-sider equilibrium). It is generally postulated that there is a natural rate of interest (akin to that postulated by Wicksell) which equates aggregate demand with aggregate supply (or equivalently which equates ex ante savings and investment at the supply-sider equilibrium level of economic activity).

This approach to monetary policy is reflected in the notion of the Taylor rule for the conduct of monetary policy in which the policy interest rate $i_{p}$ is set according to:

$$
i_{p}=p+a\left(Y-Y^{*}\right)+b(p-p t)+r i^{*}
$$

where $Y$ is the level of output and $Y^{*}$ is the target level of output, $p$ is the rate of inflation and $p t$ is the target rate of inflation, and $r{ }^{*}$ is the real policy interest rate and the one which the Central Bank perceives that it would set in the event that both output and inflation were at their target levels.

The basic argument now is that these features of monetary policy are embedded in a specific form of macroeconomic analysis (which could be summarised as the new consensus in macroeconomics) and that the Kaleckian macroeconomic analysis would provide a rather different perspective on monetary policy. ${ }^{4}$ Applying the Kaleckian analysis leads to the following conclusions pertinent for the operation of monetary policy.

4 For a critical discussion of the approach to monetary policy in the new consensus in macroeconomics see Sawyer (2006). 


\section{I Interest Rates and Demand}

The general Kaleckian view is that the level of aggregate demand will be little affected by the level of interest rates. Such doubts stem from the view that long-term interest rates were seen as relevant for many decisions but there being rather small movements in such long-term rates:

"The relative stability of the long-term rate of interest is generally known. [...] It seems unlikely that changes in the long-term rate of interest of the order of those noticed [...] can influence investment activity« (Kalecki 1990: 296 f.).

This leads him to dismiss those theories of the business cycle which suggest that the end of a boom derives from an increase in the rate of interest:

"For the rate of interest can stop the boom only by hampering investment, and it is chiefly the long-term rate which matters in investment activity" (Kalecki I990: 298). It would also be that a substantial fall in the rate of interest would be necessary to have a significant effect on investment (Kalecki 1990: 403).

Thus, aggregate demand may be rather unresponsive to interest rates, which would imply that the changes in interest rates required to generate significant changes in output and inflation may be rather large (that is of the order of several percentage points). Further, the effects of changes are likely to be a rather unpredictable way of generating changes in aggregate demand. As we pointed out in Arestis/Sawyer (2004c) empirical work (often undertaken within Central Banks) on the impact of interest rates on demand and inflation suggested that insofar as there was an effect on demand this came through an effect on investment rather than consumer demand.

The notion of using interest rates to attain the supply-side equilibrium, as it is portrayed in the NCM, is clearly undermined in the Kaleckian approach when it is acknowledged that the level of aggregate demand depends on a range of factors including fiscal policy stance, the exchange rate and the state of world trade and the buoyancy of investment (depending on the state of animal spirits and technological innovation). If there is an interest rate which would bring demand into line with supply, it is far from snatural.. Further, the equilibrium rate will be unknown and liable to change, undermining any notion of the Central Bank being able to use it in their decision making. The domestic interest rate is constrained by the level of world interest rates. Uncovered interest parity theory suggests that the rate of change of the exchange rate is equal to the difference between the foreign nominal interest rate and domestic nominal interest rate. Thus, a stable exchange rate would require the level of domestic interest rates equal to the level of global interest rates.

This brief discussion points to three conclusions. First, there is no unique equilibrium rate of interest (which could be seen as corresponding to some snatural rate of interest) but rather any equilibrium rate of interest (in the context of macroeconomic models) depends on factors such as fiscal policy and investment demand. Second, since there is no unique rate, the Central Bank cannot know the values of any equilibrium rate (nor 
we would argue the supply-side equilibrium $Y^{*}$ which is continually changing over time). Third, the effects of interest rate changes on the pact of inflation are likely to be rather small, and we would argue that this is confirmed by empirical evidence (as discussed in Arestis / Sawyer 2004c).

\subsection{Investment and its Role}

Investment is an addition to the capital stock, and clearly investment is always occurring (at different rates) and additions being made to the capital stock (the term additions will be used but it is noted that the capital stock may be diminishing through depreciation which is not covered by gross investment). The Kaleckian approach to investment has a range of features, but two related ones are significant here. First, investment (and thereby additions to the capital stock) is path dependent. There is no notion of a pre-existing optimal capital stock depending on relative prices towards which adjustment is made through investment. It is rather that the >long run is a collection of short runs . Second, investment depends on the level of and change in economic activity. Hence, when economic activity is high, investment is relatively high and more additions are being made to the capital stock. Since the level of economic activity depends on the level of aggregate demand, the additions to the capital stock depend on the level of demand.

The size of the capital stock is obviously an important ingredient in the supply capability of the economy. In the medium term at least the additions to the capital stock which take place cannot be ignored in terms of the supply side of the economy. Insofar as interest rates do have an impact it could come through investment. But if higher interest rates are used to reduce inflation and work through an impact on investment, then the future capital stock is lower than it would have been, and worsens the prospects for inflation in so far as the CILO as discussed above falls. The subsequent inflation barrier becomes more of an obstacle, and the inflationary pressures corresponding to a particular level of demand greater as the supply potential would be lower.

\section{$5 \cdot 3$ Causes of Inflation}

The Kaleckian analysis which has been sketched above suggests that the inflationary process is a complex one and can arise from a variety of sources. The one source which is though discounted is the expansion of the stock of money as a causal mechanism (though the stock of money could well expand alongside inflation). It would suggest that demand may have some effects, though with an emphasis on the role of changes in demand. Further, the effects of the level of economic activity would depend also on the distribution of income. A persistent increase in costs (say from imported goods) would clearly add to the inflationary situation. Further, an increase in costs could well set off an inflationary spiral, depending on the reactions of firms and workers.

These brief remarks are intended to suggest that demand is but one element in the 
inflationary process. Costs, struggle over the distribution of income, changes in the level of demand are amongst the other elements. Monetary policy can at best only address the demand element, and then in an ineffectual way. Insofar as monetary policy can have some impact on inflation, there would be some detrimental side effects, namely through higher interest rates depressing the level of investment with subsequent consequences for the future capital stock.

\section{Role of Fiscal Policy}

In a Kaleckian analysis, fiscal policy retains a key role in supporting the level of aggregate demand. We have discussed elsewhere (Arestis / Sawyer 2004a, 2004b and 2005b) the various objections raised against fiscal policy and found them wanting. The essence of our argument there was that fiscal policy has been dismissed by many mainstream economists by using an analytical framework in which there was no deficiency of private aggregate demand, and hence no need for fiscal policy. In contrast, the Kaleckian analysis is firmly based on the view that private aggregate demand is often insufficient to support full employment. The current vogue is to asset the role of interest rate in securing a level of aggregate demand in line with available supply, and notably the role of the natural rate of interest . The Kaleckian analysis, for reasons alluded to in the previous sections, largely dismisses those arguments. Hence there is a remaining need for fiscal policy used to influence the level of aggregate demand. Fiscal policy would be viewed as a much more potent tool than monetary policy, though we would not advocate using fiscal policy to target the rate of inflation.

\section{Concluding Remarks}

The Kaleckian analysis suggests that the relationship between inflation and the level of economic activity is a complex one, and is not the simple relationship portrayed by the Phillips curve. The Kaleckian approach postulates that variations in short-term interest rates have rather small effects on the level of economic activity. It would also suggest that the effects of interest rates on inflation would be small: in part as the effect on demand is small, the effects of demand on inflation are various, and interest rates serve to raise costs and thereby inflation. As an aside we would argue that this is borne out by the empirical work of bodies such as the Bank of England (2005), where the effects of interest rate changes are simulated and found to be small. 5 For example, Bank of England (2005: figure 7.I) shows a one percentage point rise in the policy interest rate held for a year leading to a maximum reduction in the rate of inflation of 0.3 percentage points.

The conventional approach to monetary policy is based on a form of the classical di- 
chotomy by which monetary policy in the form of interest rates may influence short-term demand but does not change the supply-side equilibrium towards which the economy is presumed to move (guided by interest rate policy). The Kaleckian analysis casts doubt on that proposition. Interest rates may have, albeit a small, impact on investment, and as such impact on the size of the capital stock, and thereby the future supply capacity of the economy. A more general proposition from the Kaleckian approach to investment would be that any policy which deflates demand, lowers economic activity and profitability, would have effects on capacity, and the future economic conditions.

\section{References}

Arestis, Philip / Sawyer, Malcolm (2004a): Reinventing Fiscal Policy, in: Journal of Post Keynesian Economics, Vol. 26, No. I, pp. 4-25

Arestis, Philip/Sawyer, Malcolm (2004b): On Fiscal Policy and Budget Deficits, in: Intervention. Journal of Economics, Vol. I, No. 2, pp. 6I-74

Arestis, Philip / Sawyer, Malcolm (2004c): Can Monetary Policy Affect the Real Economy?, in: European Review of Economics and Finance, Vol. 3, No. 3, pp. 9-32

Arestis, Philip/Sawyer, Malcolm (2005a): Price and Wage Determination and the Inflation Barrier: Moving Beyond the Phillips Curve, forthcoming

Arestis, Philip/ Sawyer, Malcolm (2005b): On the Effectiveness of Monetary and Fiscal Policy, in: Review of Social Economics, Vol. 62, No. 4, pp. 44I-463

Arestis, Philip/Sawyer, Malcolm (2005c): Aggregate Demand, Conflict and Capacity in the Inflationary Process, in: Cambridge Journal of Economics, Vol. 29, No. 6, pp. 959-974

Arestis, Philip / Sawyer, Malcolm (2006): The Nature and Role of Monetary Policy. When Money is Endogenous, in: Cambridge Journal of Economics, forthcoming

Arestis, Philip (2007): What is the New Consensus in Macroeconomics?, in: Arestis, Philip (ed.), Is There a New Consensus in Macroeconomics?, Basingstoke: Palgrave Macmillan, forthcoming

Baddeley, M.C. (2003): Investment: Theories and Analysis, Basingstoke: Palgrave Macmillan Bank of England (2005): The Bank of England Quarterly Model, London: Bank of England

Bank of England (2006): From Interest Rates to Inflation, URL: http://www.bankofengland. co.uk/monetarypolicy/how.htm

Chirinko, Robert S. (1993): Business Fixed Investment Spending: Modelling Strategies, Empirical Results, and Policy Implications, in: Journal of Economic Literature, Vol. 31, No. 4, pp. I875-I9II

Kalecki, Michal (1990): Osiatynski, Jerzy (ed.), Capitalism: Business Cycles and Full Employment, Collected Works of Michal Kalecki, Vol. I, Oxford: Clarendon Press

Lavoie, Marc (1992): Foundations of Post-Keynesian Economic Analysis, Aldershot: Edward Elgar

Meyer, Laurence H. (200I): Does Money Matter?, in: Federal Reserve Bank of St. Louis Review, Vol. 83, No. 5, pp. I-I5

Mott, Tracy (2003): Investment, in: King, John E. (ed.), The Elgar Companion to Post Keynesian 
Economics, Cheltenham: Edward Elgar, pp. 205-210

Sawyer, Malcolm (1982): Macro-economics in Question, Brighton: Wheatsheaf

Sawyer, Malcolm (2002): The NAIRU, Aggregate Demand and Investment, in: Metroeconomica, Vol. 53, No. I, pp. 66-94

Sawyer, Malcolm (2006): A Critical Reconsideration of the Foundations of Monetary Policy in the New Consensus Framework, forthcoming 
